\title{
Die integrering van prys-/kosteberaming en konstruksiebeplanning - die gerekenariseerde generering van konstruksiebedrywighede
}

\author{
P.A. Bowen* \\ Departement Konstruksie-ekonomie en -bestuur, Universiteit van Kaapstad, Rondebosch, 7700 \\ (Besoekende Professor, Departement Bourekenkunde, Universiteit Glasgow Caledonia, Skotland)
}

G.J. Erwin

Afdeling Besigheidsinligtingstelsels, Departement Rekeningkunde en Finansies, Universiteit van Durban-Westville, Durban, 4001

G.K. le Roux

Departement Bourekenkunde, Universiteit van Port Elizabeth, Posbus 1600, Port Elizabeth, 6000

Ontvang 29 Augustus 1995; aanvaar 16 September 1996

\section{UITTREKSEL}

Die feit dat Iradisionele prys-/kostemodelle glad nie op die konstruksieproses betrekking het nie, maak dié modelle grootliks ongeskik vir die verskaffing van sinvolle advies oor pryse/koste. Die aard en duur van die konstruksiebeplanningsproses maak dit by voorbaat onmoontlik om dit gedurende die voortenderfase van die tradisionele bouverkrygingsproses by prys-/kosteberaming in te sluit. Die kern van die modelleringsprobleem is hoe om die ingewikkelde konstruksiebeplanningsproses reeds in die voortenderstadium in die prys-/kosteberamingsproses te integreer. In dié verhandeling stel die skrywers voor dat kunsmatige intelligensietegnieke en konstruksiebeplanningstegnieke gesintetiseer word oin 'n konseptuele raamwerk te verskaf vir ' $n$ netwerkgebaseerde prysberamingstelsel wat bourekenaars tydens die kosteberekening van geboue kan gebruik. Daar word aangevoer dat so ' gehalte van die interpersoonlike kommunikasieproses van die bourekenaar kan verbeter, waardeur die doeltreffendheid van die interpersoonlike oordra van prys-/kosteboodskappe verhoog kan word.

\begin{abstract}
The integration of price/cost modelling and construction planning - the automated generation of construction operation

The fact that traditional price/cost models are unrelated to the construction process renders them largely unsuited to the provision of meaningful price/cost advice. The nature and lengthiness of the construction planning process has precluded its incorporation into price/cost modelling during the pre-tender phase of the traditional building procurement process. The nub of the modelling problem has been how to integrate the complex process of construction planning into the pre-tender price/cost modelling process. In this paper the authors propose the synthesis of artificial intelligence techniques and construction planning techniques, resulting in a conceptual framework for a network-based cost modelling system for use by quantity surveyors in the cost modelling of buildings. It is suggested that such an approach has the potential for improving the quality of the intrapersonal communication process of the quantity surveyor. thereby enhancing the effectiveness of the interpersonal communication of price/cost messages.
\end{abstract}

\section{INLEIDING}

Volgens literatuurbronne word heelwat navorsing deesdae gedoen oor die toepassingsmoontlikhede van ekspertstelsels vir die konstruksiebedryf. Voorbeelde hiervan sluit in ekspertstelsels vir: konstruksietyd- en -koste-analise;' baksteenbekledingsontwerp; ${ }^{2}$ foutdiagnose vir steenwerk; $;^{3}$ projekbestuur; ${ }^{4}$ en die strategiese beplanning van konstruksieprojekte. ${ }^{5}$ Die volgende tegnieke geniet tans ook baie aandag: kennisinsamelingstegnieke vir konstruksie-ekspertstelsels; ${ }^{6}$ reëlgenerering ${ }^{7}$ en die evaluering van ekspertstelseldoppe vir aanwending in die konstruksiebedryf .

Dit val buite die bestek van dié artikel om 'n uitvoerige uiteensetting te gee van navorsing oor ekspertstelsels en verwante kwessies wat op die konstruksiebedryf van toepassing is. Daar word volstaan met 'n oorsig (sien tabel I) van sommige van die modelle wat ontwikkel is om die kundigheid van konstruksiebeplanners in te span wanneer besluite oor ontwerpe geneem word. Die modelle voorgestel deur Bennett en Ormerod, "Thompson en Willmer, ${ }^{10}$ Gray, ${ }^{\prime}$ Brandon et al." en Howes ${ }^{4}$ is voorbeelde hiervan. Die doel van dié gedeelte is om insig te gee in die moontlikheid om die kern van die kennis en die interpersoonlike kommunikasieprosesse van konstruksiebeplanners binne ekspertstelsels weer te gee.

Die aard van die modelle wat infra getabuleer word, toon die vordering wat reeds gemaak is met die vaslegging van die tersaaklike konstruksieverwante kundigheid vir gebruik tydens die voortenderfase van bouprojekte. Ekspertstelsels moet klaarblyklik nie as 'n spesifieke prys-/kosteberamingstegniek beskou word nie. Hulle moet eerder beskou word as stelsels 
wat 'n geskikte omgewing vir die implementering van toepastike' prys-/kosteberamings bied; 'n omgewing wat dit moontlik malak om deskundiges se interpersoonlike kommunikasieprosesse vas te tê op 'n wyse wat logies deursigtig vir dic gebruiker is. Bowen" het 'n kommunikasiegebaseerde benadering tot prysvoorspelling beskryf.

Alhoewel modelleringstelsels oor die algemeen voldoen aan hul beoogde doel om 'n regstreckse band ussen ontwerpsbesluite en die konstruksieproses te skep, is daar ellike beperkings wat dic praktiese toepassing van selfs die gevorderdste van dié stelsels belemmer.

Dié beperkings kan soos volg saamgeval word (aangepas van Marston en Skitmore ${ }^{12}$ ):

- Dic operasionele plan vir dic projek word met dic hand opgestel. Dic kennis wat nodig is vir planontwikkeling in dic aanvanklike projekfases is gewoonlik nie toeganklik nic. Dic konvensionele beplanningstegnicke wal gebruik sal moet word, is boonop gedetailleerd van aard en tydrowend om voor te berei. Waar planont wikkeling met dic hand nic nodig is nic, is die gegenerecrde planne nic uitvocrig van aard nie. Mel ander woorde, 'n aansienlike hoeveclheid aanvullende menslike kundigheid word steeds vir die skep van operasionele planne vereis. Kortom: die "model" in die rekenaar is dus onvolledig.

- Waarskynlikheidsverdelings moet omskry! word vir alle betekenisvolle veranderlikes wat in die stelsel vervat word. Weens die gebrekkige empiriese gegewens is die omskrywing van dié verdelings gewoonlik subjektief van aard.

- Dic afvoer van dié modelle is dikwels in 'n ongewone formalat, wat dit moeilik maak om te verstaan. Dit belemmer kommunikasic, aangesien dic gebruiker, wat die toepaslike "gedagtemodel" betref, nie met dic alvoer vertroud is nic. Dit beimvloed weer die dekoderingsproses.

- Dié stelsels dek nie die belangrike aspek van bestuurskontrole gedurende die konsiruksiefase nie.

Wanneer dic potensiaal van dié modelle as voertuie vir die verbetering van die interpersoonlike kommunikasieproses wat met kostcberaming gepaardgaan, bespreck word. moet kennis geneem word van die doel van dié werktuic. Die doel van die modelte is naamlik om as voertuic te dien vir die generering van inligting vir gebruik in die interpersoonlike proses van die oordra van prysboodskappe op so 'in wyse dat gedeelde betekenis gemaksimaliseer word en doeltrelfende kommunikasie bevorder word. Van voormelde beperkings is die eerste miskien die crnstigste, aangesien dit dic bruikbaarheid van sodanige stelsels as 'n metode om proaktiewe ontwerp-tot-koste-advies gedurende

TABEL 1 'n Keuse van modelle vir prys-/koste-/tydsberaming gebaseer op ekspertstelsels

\begin{tabular}{|c|c|c|}
\hline Model & Ontwikkelaar(s) & Beskrywing \\
\hline Konstruksieprojeksimulator & Universiteit van Reading ${ }^{9}$ & $\begin{array}{l}\text { 'n Stogastiese simulasiegebaseerde konstruksie- } \\
\text { beplanningsmodel wat die belangrike kenmerke } \\
\text { van veranderlikheid en steuring uitdruklik kan } \\
\text { identifiseer en insluit. Projekinligting word } \\
\text { hiërargies gerangskik, gebaseer op die aktiwiteite } \\
\text { waardeur die gebou opgerig word. Hiërargiese } \\
\text { stafiekaarte word gebruik }\end{array}$ \\
\hline $\begin{array}{l}\text { Rekenaargesteunde simulasie } \\
\text { vir projekbeoordeling en } \\
\text { hersiening }\end{array}$ & $\begin{array}{l}\text { Universiteit van Manchester } \\
\text { Institute of Science and } \\
\text { Technology }{ }^{10}\end{array}$ & $\begin{array}{l}\text { 'n Netwerkgebaseerde stelsel wat stogastiese si- } \\
\text { mulasie gebruik vir die evaluering van die risiko } \\
\text { verbonde aan strategiese ontwikkelingsbesluite vir } \\
\text { groot ingenieurskemas. Wesenlik 'n modifikasie } \\
\text { van die PERT-benadering }\end{array}$ \\
\hline $\begin{array}{l}\text { "Intelligente" konstruksietyd- } \\
\text { en koste-analise }\end{array}$ & Universiteit van Reading' & $\begin{array}{l}\text { Ontwikkel om 'n voorspelling van die totale kon- } \\
\text { struksietyd te voorsien wanneer alternatiewe kon- } \\
\text { struksiemetodes oorweeg word. Benut kennis } \\
\text { verkry van konstruksiebeplanningsdeskundiges vir } \\
\text { die seleksie van aktiwiteite, die bepaling van 'n } \\
\text { voorranglys en die raming van die duur. Stafie- } \\
\text { kaarte word gegenereer }\end{array}$ \\
\hline $\begin{array}{l}\text { Die strategiese beplanning } \\
\text { van konstruksieprojekte }\end{array}$ & $\begin{array}{l}\text { Universiteit van Salford en } \\
\text { R.I.C.S. }\end{array}$ & $\begin{array}{l}\text { Ontwerp om gebruik te word in die strategiese be- } \\
\text { planning van kommersiële bouprojekte alvorens } \\
\text { formele ontwerp. Integreer die kennis van boureke- } \\
\text { naars en konstruksiebeplanners. Bestaan uit vier } \\
\text { verbandhoudende modules: kosteberaming, } \\
\text { aanskaffing, voltooiingstyd en ontwikkelings- } \\
\text { beraming. Verslae word gegenereer }\end{array}$ \\
\hline $\begin{array}{l}\text { Projekbestuur, kostebeheer } \\
\text { en verslagdoeningstelsel }\end{array}$ & Howes $^{4}$ & $\begin{array}{l}\text { Die ontwerp van 'n projekbestuurstegniek om in } \\
\text { die beplanningstaak te assisteer, finansiële } \\
\text { beheer, kontrolering en verslaggewing oor bou- } \\
\text { projekte. Stafiekaarte word gegenereer }\end{array}$ \\
\hline
\end{tabular}


die voortenderlise te voorsien, alansientik beperk. Die ander beperkings is minder ernstig van aard, allocewel hulle nic onbenullig is nic. Ten spyte van die beperkings verteenwoordig dic ontwikkeling van bogemelde modelle belangrike vordering in dic proses om 'in metode te vind om konstruksiekundigheid en prys-/kosteberaming te integrecr.

Tydens konvensionele konstruksicheplanning word planne mel die hand geformuleer, gewoonlik op 'n intuiticwe en ongestruklureerde wyse, mel die klem op subjekliewe oordecl en ondervinding. ${ }^{13}$ Die skep van PERT/KPM-netwerke is tradisionecl 'n langsame proses wartydens konstruksiebeplanners planne vanal projeklekeninge opstel. Ondervinding en netwerke wat van vorige projekte verkry is, is belangrike werktuie in die beplanningsproses. Weens die aard en duur van dié proses kan dil nie gedurende die voorlenderfise van die tradisionele bouverkrygingsproses by prys-/kosteberaming ingesluit word nic. Die kern van die probleem is dus hoe om tydens die voortenderfase die komplekse konstruksiebeplanningsproses met die prys-/kosteberamingsproses te integreer.

Sedert Newell en Simont is gerekenariseerde beplanning ' $n$ kenmerk van navorsing oor kunsmatige intelligensic. Marston en Skitmore'2 verklaar met verwysing na Sacerdoti ${ }^{15}$ en Nillson ${ }^{16}$ dat dic beplanningstaak ingevolge navorsing oor kunsmatige intelligensie omskryl word as die vooralbepaling van 'n transformasieproses deur dic keuse van 'n reeks handelinge wat, wanneer dit chronologies gerangskik word, 'n aanvanklike situasie in 'n "doelwil"-situasie sal omskep. Planne kan ôl lineêr wees, waar akliwiteite in volgorde benader word, óf nie-lineêr (kenmerkend van konstruksicbedrywighede) waar aktiwiteite dikwels tegelykertyd plaasvind.

Formoso ${ }^{17}$ verskal' 'n opsomming van navorsingspogings oor die skep van kunsmatige-intelligensiestelsels vir konstruksicprojekte wal die beplanningsproses kan rekenarisecr. Dil sluit die werk van Levilt en Kunz, ${ }^{18}$ Gray, ${ }^{1}$ Hendrickson et al., ${ }^{13}$ Ibbs en De La Garza, ${ }^{10}$ Navinchandra et al. ${ }^{20}$ en Alshawi en Jaggar ${ }^{21}$ in.

Die modelle wat in die Verenigde Koninkryk ontwikkel is, het hul ontstaan hoolsaaklik te danke aan die vraag in die bourckenaarsprolessie na 'n meganisme waarvolgens produksiekennis gedurende die vroeë ontwerpstadiums as 'n laktor in prys/koste-/lydsberaming ingevoer kan word. Die modelle van Gray' en Brandon et al. ${ }^{5}$ is byvoorbeeld nutlige werktuic vir die voorspelling van die duur van projekte (cn hoolstadiums) en vir die vergelyking van verskillende ontwerpsalternatiewe wat konstruksietyd as 'n kriterium gebruik. Dic modelle behels wesenlik prysvoorspellingstegnieke wat konstruksiemetodes en die duur daarvan in aanmerking neem. ${ }^{17}$

In die Verenigde Slate van Amerika word navorsing hootsaaklik gerig op die gebruik van KPM-tegnieke vir konstruksiebeplanning. Dié navorsing word veral gerig op dic gerekenariseerde bywerking van netwerke, ${ }^{18}$ die kritisering en validering van netwerke, ${ }^{19}$ die raming van aktiwiteitsduur ${ }^{13} \mathrm{en}$ die bepaling van aktiwiteitsvoorrange. ${ }^{20}$

Opsommenderwys kan dié navorsing in twee hoofkategorice ingedeel word, naamlik die navorsing wat oor die kwessic van kennisinsameling handel (byvoorbecld Gray;' Hendrickson et al.; ${ }^{13}$ Brandon et al. ${ }^{5}$ en die navorsing wat oor kennisvoorstelling en inferensiemeganismes handel (byvoorbeeld Navinchandra et al.). ${ }^{20}$

Dié ontwikkelings in die rekenarisering van konstruksicbeplanning en die vaslegging van konstruksiekundigheid hou klaarblyklik belolite in vir dic oplossing van 'n aantal probleme wat supra geidentiliseer is in die toepassing van produksicgebaseerde simulasiemodelle vir prys-/koste-/tydvoorspelling.

Meer spesifiek: 'n aantal potensiële voordele sal waarskynlik uit die loepassing van so 'n ekspertstelsel-gebaseerde benadering verkry word. Eerstens sal die lasiliteit om die konstruksieplan te modiliseer of by te werk die gebruiker in slatat stel on die uitwerking van verskillende ont werpsbesluite en/of konstruksiemetodes ten opsigte van kosle, tyd en hulpbronbenutting te simuleer. Tweedens sal sodanige stelsels, afgesien van die klaarblyklike voordeel van die fasilitering van die opsicl van produksieplanne, die kundigheid van deskundiges ook vir nicdeskundiges loeganklik maak. Mel ander woorde, die bourekenaar sal in staat gestel word om die stelsel te gebruik sonder dat hy noodwendig oor die vereiste uitvocrige kennis van konstruksiebeplanning hoef te beskik. Dil kan moontlik 'n positiewe nitwerking op die gehalte van die interpersoonlike kommunikasieproses verbonde aan prys-/kostcheraming hê, dit wil sê beter voorbereiding vir die interpersoonlike kommunikasieproses wall volg. Dit sal daarbenewens die vroec, proaktiewe betrokkenheid van die bourekenalar in die bouverkrygingsproses liasiliteer.

Laaslens kan die probleem van die verkryging van geskikte dala vir die stogastiese behandeling van veranderlikes in die proses (byvoorbecld aktiwiteitsduur) aanvanklik opgelos word deur die loepassing van reelgebasecrde legnicke vir die modilikasie van standalardgegewens. ${ }^{13}$ 'n Ander benadering sou wees om 'n "geskiedeniskenmerk" gebaseer op die bywerking van die konstruksieplan, wal gegewens vir veranderlike verdelings vergader, in le sluit. 'n Bykomende kemmerk kan die vermö̈ wees om intydse bestuursbeheer vir die ondersoek van ontwerps- en konstruksie-alternatiewe nate boots.

Dil wil dus voorkom asof dit moontlik is om 'n hulpbrongebaseerde, stogastiese modelleringsomgewing deur die integrering van konstruksicbeplanningstegnicke, ekspertstelsels en stogastiese simulasie te skep. Datar word aan die hand gedoen dat die vereniging van dic ontwerps- en konstruksiefunksies dic sinergic sal skep wat die onmisbare skakel tussen ontwerpsbesluite en die konstruksieproses sal verskal en walarskynlik die aard en gehalte van die prysadviesmededelings van bourekenaars positiel sal beinvloed.

\section{'N KONSEPTULLE RAAMWERK VIR 'N KOSTEBERA- MINGSTELSEL}

Hierkragtens word kunsmalige-intelligensietegnieke en konstruksiebeplanningstegnicke gesintetiseer, wat 'n konseptuele ramwerk bied vir' 'n netwerkgebaseerde kosteberamingstelsel wat bourckenaars kan gebruik wanneer hulle prysadvies gee. Dalar word alangevoer dat so 'n benadering moontlik die gehalte van die intrapersoonlike kommunikasieproses van die bourckenaar sal verbeter, waardeur die clocltreliendheid van die interpersoonlike oordrag van prysboodskappe verhoog sal word.

Die beoogde konseptuele ramwerk is gebaseer op die voorstelle van Bowen en Erwin, ${ }^{22}$ 'n Uitvoerige beskrywing van dié voorstelle word verval in dic South African Joumal of Science. ${ }^{22}$ Daar word voorgestel dat KPM/PERT-netwerke as dic basiese prysberamingstruktuur gebruik word.

Vir 'n gegewe struktuur, hetsy 'n kantoorgebou of 'n fabrick. kan 'n stel toepaslike operasionele bö̈ vir gegewe elemente of gedeeltes van die werk omskryf word. Die konstruksieboë van loepassing op 'n kommersiéle gebou wat uit 'n winkelpodium en uit 'n kantoortoring bestaan, sal hyvoorbecld 'n funksie van die elemente en werkgedecltes inherent aan dič projek wees. Kenmerkende boë sal die fondasie, kelderkonstruksic en strukluurraamwerke vir beide die winkelpodium en die kantoortoring insluit. Die toepaslike stel boé vir enige spesificke gebou sal 'n lunksie van ontwerpsparameters soos die gebouuitleg, grootte en interelement-verhoudings, byvoorbeld 
ontwerpsparameters, wees. Sodanige inligting sou insette deur die gebruiker wees in antwoord op navrae deur die stelsel.

Dié vorm van voorstelling is klaarblyklik baie abstrak: die konstruksieproses word deur 'n kern- of primêre stel konstruksieboë voorgestel. Die aantal boë sal wissel na gelang van die ingewikkeldheid van die projek. Figuur 1 illustreer die konsepkonstruksieboë.

Die konstruksieboog vir 'n spesifieke element of gedeelte van die gebou (byvoorbeeld die gewapendebeton-raamwerk) sal gepaardgaan met ' $n$ netwerk konstruksiebedrywighede wat operasionele prosedures op 'n uitvoeriger vlak weerspieèl. In die lig daarvan dat ' $n$ keuse van netwerke uit 'n familiegroep van tersaaklike netwerke vir 'n spesifieke konstruksieboog bestaan, is dit duidelik dat aandag aan die probleem van die keuse van 'n geskikte netwerk gegee moet word.

Dit is hier waar ekspertstelsels as van besondere belang beskou word, aangesien dit 'n metode bied waarvolgens toepaslike netwerkmodules geîdentifiseer en ingesluit kan word. Die seleksieprosedure moet verkieslik op verskillende vlakke van netwerkabstraksie plaasvind en die beskikbaarheid van inligting op die bepaalde ontwerpstadium weerspieël - wesenlik 'n hiërargie van netwerkvoorstelling (sien figuur 2).

Net 'n beperkte getal moontlike netwerkkonfigurasies vir enige diskrete bou-elementproses (boog) is beskikbaar. Die presiese netwerkkonfigurasie wat gekies word om die projekelement (boog) in oorweging voor te stel, word bepaal as 'n funksie van ontwerpparameters en ander gebruikersinsette.

Saam met elke konstruksienetwerk gaan die fisieke en ander parameters wat die spesifieke konstruksieproses omskryf. Met betrekking tot die konstruksie van 'n struktuurraamwerk sou sodanige data byvoorbeeld inligting insluit soos die toepaslike groottes van werkspanne, produktiwiteitsyfers, die teenwoordigheid en spasiëring van pilare, betonmengsels, die tipe staalbewapening en die belastings waaraan die struktuurdele onderwerp sal word. Wanneer sodanige inligting afwesig is, wat gewoonlik in die vroeè ontwerpstadiums die geval is, word verstekdata met betrekking tot ontwerp-/konstruksienorme gebruik. Sodanige verstekdata word dan in 'n geskikte databasis bewaar. Die databasis sal wesenlik uit twee (of meer) databasisse bestaan: die een sal die insetwaardes bewaar, en die ander inligting soos relevante konstruksiekoste.

Saam met elke netwerk en die kennisdatabasis gaan funksies wat die duur, koste en hulpbronne van die konstruksie-aktiwiteite beskryf. Kennisdatabasisse wat verband hou met die duur-, koste- en hulpbronvereistes sal 'n funksie van gebruikersinsette wees en verander na gelang die waardes van die ontwerpsparameters verander. Die duur en koste van elke netwerk sal presies bereken kan word omdat die verhoudings as voorafbepaalde funksies (algoritmes) omskryf deur die bourekenaar en/of konstruksiebeplanner uitgedruk kan word.

Uit bostaande volg dit dat die parameters wat die tersaaklike konstruksie-aktiwiteitsnetwerke aanvanklik omskryf het, nou uitgebrei kan word om enige kennis van of inligting oor die duur, koste en hulpbronne van elke konstruksie-aktiwiteit in die netwerk in te sluit. Die parameters wat elke aktiwiteit omskryf, kan verder uitgebrei word om alle faktore wat as relevant beskou word, in te sluit.

Sodra die netwerk en verwante aktiwiteite ten opsigte van die betrokke boog (element) gekies is, word dit gebruik om die duur en koste van die netwerk ingevolge die vasgelegde voorwaardes te bereken. Die aggregasiebeginsel word dan gebruik om die totale koste en duur van die netwerk en die hulpbronvereistes te bereken.

Die model behoort verbeter te kan word deur die gebruik van stogastiese simulasie om ' $n$ waarskynlikheidsdimensie aan die tyds- en kosteberaming te verleen. Deur steekproewe van bekende of veronderstelde verdelings van die faktore en koste betrokke in die bou-(netwerk-)proses te doen, behoort dit moontlik te wees om die verwagte waarde van die faktore (byvoorbeeld deur aggregasie) te bereken, asook hul verwante waarskynlikheidsverdelings.

Uit die voorafgaande wil dit lyk asof dieselfde logika op al die ander konstruksieboë van die bouproduksieproses toegepas sal kan word. Op dié wyse sal 'n konstruksienetwerk vir die hele projek geskep kan word.

Die konseptuele raamwerk wat hierbo geskets word, sal nie beperk wees tot die netwerke wat in die kennisbasis vervat word nie. Dit wil voorkom asof die geskikste netwerk uit die kennisbasis getrek sal kan word en dat dié netwerk se voorstelling van die betrokke element (boog) dan geëvalueer en, waar nodig, gewysig sal kan word (via ' $n$ redigeerproses) om die spesifieke konstruksieproses wat gemodelleer word, akkurater voor te stel. Silverman en Moustakis $^{23}$ het 'n nuttige benadering voorgestel vir die klassifisering van projekte met soortgelyke funksionele kenmerke. Die logiese uitbreiding van dié benadering is dat die netwerkkennisbasis vergroot kan word na gelang meer netwerke bygevoeg word. Dié redigeerprosedure kan ook op die totale (gekonstrueerde) projeknetwerk toegepas word.

Daar word voorsien dat die netwerkgebaseerde modelleringstelsel, waarvan die algemene uitleg in figuur 3 uitgebeeld word, die volgende komponente sal bevat:

- Ekspertstelseldop - die inferen-

FIGUUR 2: Konstruksienetwerkvoorstelling van primêre boë (byvoorbeeld boog A6). 
siemasjien wat die manipuleringsreëls op die kennisbasis toepas.

- Kennisvoorstelling - die distillering van die "kundigheid" van argitckte, bourckenaars en konstruksiebeplanners.

- Databasis van projekte - werklike data van projekte, soos gehaltespesifikasies, koste, tydsberekening, duur, hulpbronvereistes en masjinerie.

- Databasis van konstruksienetwerke - die bewaring van tipiese "skelet"-netwerke van verskillende gebou-elemente (boë) vir verskillende projekklassifikasies.

- Hoofparameters - agtergrondsinligting oor ekonomiese en bedryfstoestande, byvoorbecld die inflasiekoers, die mededinging op die mark en die beskikbaarheid van werk.

- Gebruikerskoppelvlak - modules wat die gebruiker in staal stel om met die ekspertstelselomgewing te kommunikeer, byvoorbeeld skerm met grafiese vertoon.

Elkeen van dié komponente sal nou kortliks bespreck word. 'n Uitvoerige uiteensetting word deur Bowen en Erwin ${ }^{22}$ verskaf.

\section{Ekspertstelseldop}

Vir die insluiting van die konstruksiebeplanningsproses, asook ander relevante kennis, moet ' $n$ stelselontwikkelingshulpmiddel vir 'n kennisbasis gekies word wat 'n geskikte omgewing bied vir die voorstelling van konstruksiebeplanningskennis. Die basiese tipes domeinspesilieke kennis wat voorgestel moet word, is feite, opinies, omskrywings, heuristiese oordele en prosedures. Produksiereëls en raamwerkgebaseerde voorstelling is reeds met welslac in die generering van konstruksiebeplanningsprosesse gekombineer. ${ }^{13.24}$ 'n Sterker ontwikkelingsomgewing sal produksiereëls, raamwerke, alternatiewe vir soekstrategieë en die vermoë om newelagtige ("fuzzy") verhoudings te hanteer, insluit. ${ }^{2 s}$

Allwood ${ }^{26,27}$ en Allwood et al. ${ }^{28}$ het ' $n$ evaluering van die geskiktheid van 'n seleksie ekspertstelseldoppe vir die konstruksiebedryf opgeteken. Dic Leonardo Shell' ${ }^{29}$ is 'n voorbeeld van een van dic kommersieel beskikbare ekspertstelsels en word as geskik vir die voorstelling van konstruksiebedrywighede beskou. ${ }^{17 .}{ }^{25}$ Dié spesificke dop, wat op 'n objekgerigte wyse gestruktureer is, gebruik reëls en raamwerke gelyktydig as kennisvoorstellingstrukture.

\section{Kennisvoorstelling}

Daar bestaan etlike verskillende metodes vir die voorstelling van kennis. Die keuse van 'n metode word beïnvloed deur dic tipe kennis wat voorgestel moet word. Twee metodes wat met welslae vir die voorstelling van konstruksiekennis gebruik word, is reëls en raamwerke. ${ }^{17.24}$

Reëls vir die netwerkgebascerde prysberamingstelsel kan via verskillende implementeringstale gespesifiseer word, byvoorbeeld deur "C", PASCAL, PROLOG of LISP. Die reëltaal in die Leonardo Shell is byvoorbeeld op eerste-orde-gesegdelogika gebaseer: gesegdes ("predicates") soos "is", “includes", "overlaps", "excludes" en "equivalent" word gebruik.

Ook raamwerke kan gebruik word om konstruksickennis voor te stel. Elke objek in Leonardo kry byvoorbeeld 'n raamwerk, wat verskeie gleuwe bevat. Dié gleuwe word gebruik om boodskappe te vertoon, inferensie te beheer, inligting oor die eienskappe van objekte te bewaar en skerms te genereer. Raamwerke kan daarbenewens hiërargies georganiseer word met die gebruik van spesiale objekte (klasobjekte) - dit fasilitecr dic ondersteuning van eienskapsoorerwing.

Kennisvoorstelling gebaseer op geskrewe tekste ${ }^{3 \cdot-32}$ bied 'n alternaticf vir reëls en raamwerke en is na bewering van besondere nut danksy die vermoë wat dit het om tydgebaseerde athanklike gebeurtenisse te manipuleer. Bowen en Erwin ${ }^{31}$ beskryf hoe dié gebeurtenisse in dic evaluering van gebouontwerpe aangewend kan word. Konstruksienetwerkgebeurtenisse vertoon onder meer dieselfde kenmerke as geskreweteksgebeurtenisvolgordes, naamlik dutur ('n begin en 'n einde), afhanklikheid (gebeurtenisse wat voor/na ander plaasvind) en stereotipe aspekte (dic gebeurtenisvolgordes is dikwels voorspel-

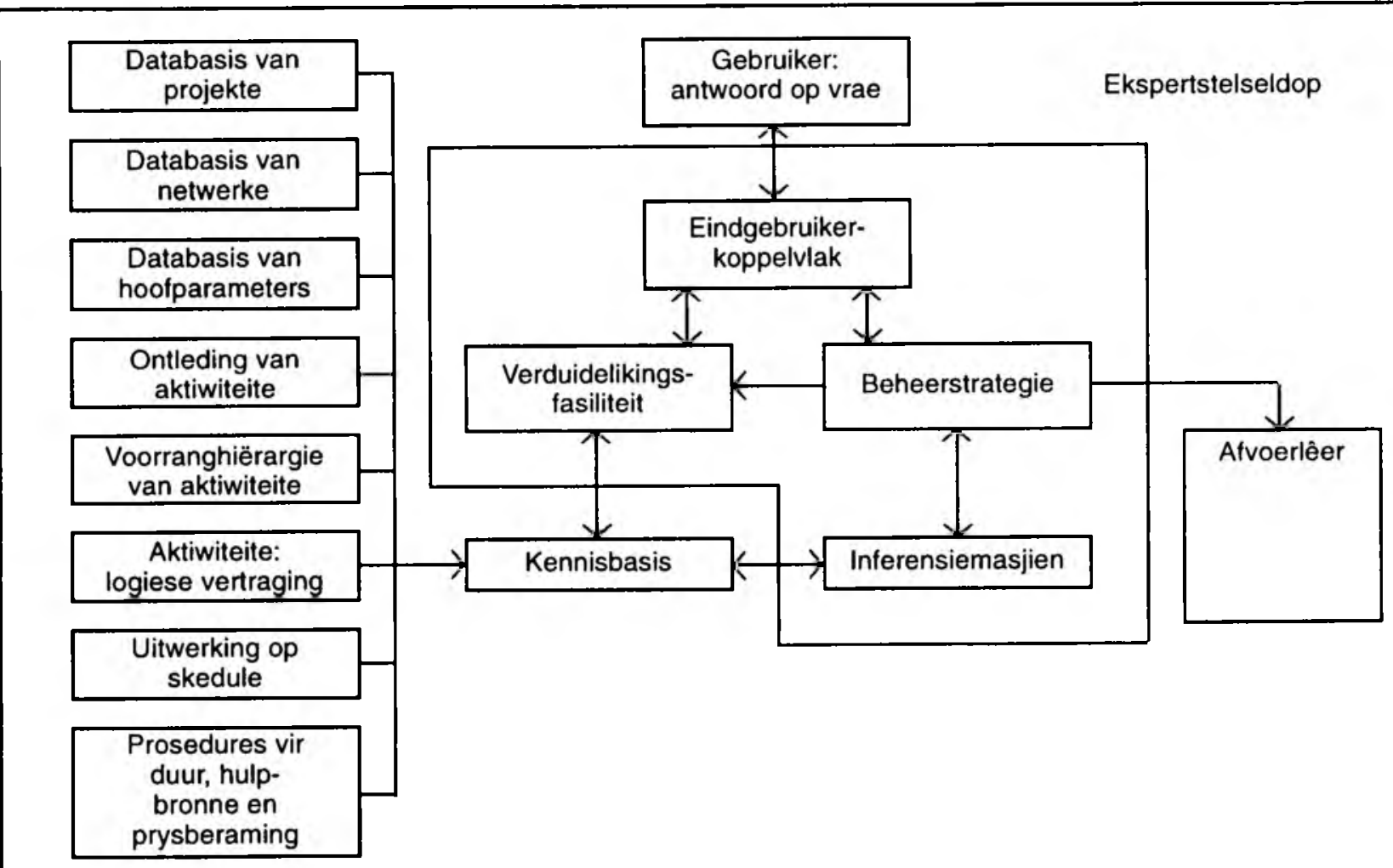

FIGUUR 3: Algemene uitleg van die konseptuele raamwerk van 'n prysberamingstelsel. 
baar en word goed verstaan). Daar word aangevoer dat geskrewe tekste die voordele bied dat dit eienskappe oorer ${ }^{32}$ en doeltreffende deurkruising deur die kennisvoorstellingstruktuur verseker. ${ }^{34}$

By geskrewetcks-gebaseerde kennisvoorstelling geld elke geskrewe teks se omskrywings spesifick vir die toepassing. Die geskrewe tekste in 'n netwerkgebasecrde model sal dus dic volgende eienskappe hê:

- die hulpbronne wees wat vereis word deur die gebeurtenisse in die geskrewe teks;

- mense wat rolle het om in die gebeurtenisse van die geskrewe teks te speel;

- daar sal aan voorwaardes (ingangsvoorwaardes) voldoen moet word voordat die gebeurtenisse vervat in die geskrewe teks verrig kan word. Die geskrewe teks sal in werking gestel kan word eers wanneer daar aan dić voorwaardes voldoen is;

- gebeurtenisse ('n gebeurtenisvolgorde) moet verrig word wanneer' $n$ bepaalde geskrewe teks ingeroep word;

- die uittreevoorwaardes waaraan voldoen moet word voordat die gebeurtenisvolgorde bečindig kan word; en

- die "doel" van die geskrewe teks. Dit behels 'n beskrywing van die resultate wat sal intree nadat die geskrewe teks se gebeurtenisvolgorde volledig deurloop is.

'n Voorbeeld van 'n geskrewe teks vir die gebeurtenisvolgorde van ' $n$ in situ-betonblad-en-balkstelsel (eerste verdieping) word in figuur 4 uitgebeeld. By so 'n ekspertstelsel kan beide voorwaartse en terugwaartse denke gebruik word. 'n Bourckenaar sal by voorbeeld dikwels voorwaartse denke gebruik om risiko's voortspruitend uit stappe en simptome in die projek te voorspel. Terugwaartse denke stel die bourekenaar weer in staat om 'n risiko of voorwaarde wat moontlik reeds teenwoordig is, in te voer en om bevestiging van die teenwoordigheid van dié risiko of toestand te probeer verkry.

\section{Databasis van projekte}

Daar word in dic vooruitsig gestel dat dié databasis al die dokumentasie van voltooide projekte sal bevat. Meer spesifiek: gegewens soos die gehaltespesifikasie van die projek, tersaaklike ontwerpinligting, die konstruksiemetode, die operasionele volgorde, die totale koste en die duur van die projek sal in dic databasis bewaar word. Dié gegewens, asook klassifikasicinligting, sal die ekspertstelsel help om nuwe projekte by "soortgelyke" vorige projekte te pas.

Sodanige gegewens sal daarbenewens die grondslag verskaf waarop die verstekdatabasis gebruik kan word vir dic aanvanklike bepaling van hulpbrongebruik, tyd en koste.

\section{Databasis van netwerke}

Die beoogde netwerkgebaseerde modelleringsbenadering sal nou oorweeg word. Aangesien die projek deur die bourekenaar beskryf word, help die stelsel die gebruiker met dic keuse of skep van 'n tipologie van konstruksieboë vir daardie tipe projek uit 'n hele reeks boč vir verskillende bou-elemente. Elke boog word ien volle deur 'n geskrewe teks en/of 'n raamwerk gespesifiseer. Die stelsel sal die gebruiker dan help om 'n geskikte netwerk (op 'n uitvoeriger vlak) uit 'n recks relevante netwerke te kies om elke spesilieke boog te vervang. "Skelet"netwerke kan aangepas word vir die spesifieke projek wat
Name van geskrewe teks

Hulpbronne

Rolle

Ingangsvoorwaardes

Gebeurtenisvolgorde

Uitgangvoorwaardes

Resultatc
Gict van betonblad-en-balkstelscl

Betonmengers, gewapende beton, werkers en operateurs

Terreinvoorman, vocrtuigdrywers, werkers, betonleweransier, struktuuringenicur

Steunkolomme gegiet, nabchandel en gestroop; blad-en-balkvormwerk in posisie; staalwapening in posisic en goedgekeur deur ingenieur; diensleidings in posisie, betonaflewering bevestig deur leweransier; en gunstige weervoorspelling

: INDIEN dit reën, DAN kansellering van dié gebeurtenis

: bevestiging van aflewering

: voorbereiding van terrein om toegang te verseker

: bymekaarkry van werkers

: skedulering van die tou wat deur afleweringsvoertuie gevorm word

: toesig oor gietwerk deur werkers

: giet van beton

: afvlakking en nabehandeling van blad

Afvlakking en nabehandeling van blad voltooi; betontoctskubusse geneem; ingenieur tevrede met uitslag; afleweringsbricwe aanvaar deur voorman

Die betonblad-en-balkstelsel van eerste verdieping in posisic en gebind; vormwerk kan gestroop word en daar kan met baksteenwerk begin word 
oorweeg word. Dié skelet-netwerke sal die lipiese gebeurtenisse, hulpbronne en afhanklikhede wat vir daardic komponent van die projek vereis word, beval. Afsonderlike skelet-netwerke sal byvoorbecld bestaan vir dic voorbereiding van die terrein, heiwerk, die lê van fondasies en grondverdiepingkonstruksie. Deur die hele konsultasieproses heen word dié skelet-netwerke dan deur die ekspertstelsel gekonsolideer in 'n enkele netwerk vir dic hele projek.

In die vroee ontwerplases sal pogings om 'n uitvoerige KPM/ PERT-netwerk op te stel moontlik nie geregverdig wees nie; dit is gewoonlik ook nie moontlik nie. Die ekspertstelsei sal 'n stel "proficlvorm"-netwerke waartoe toegang verkry kan word en wat by dic individucle projek aangepas kan word, insluit. 'n Rowwe netwerkskelet kan vir gebruik deur die bourekenaar "afgetrek" word. Dit kan ól deur die ekspertstelsel self gedoen word óf spesifick deur die bourekenaar aangevra word. Dic keuse van 'n tersaaklike profielvorm-netwerk deur die ekspertstelsel vereis die vermoë om die bourekenaar se projekbeskrywing by dié van die gestoorde proficlvorme te pas. Die ekspertstelsel sal die bourekenaar aanpor om die gegewens te verstrek wat die stelsel nodig het om so 'n keuse uit te oelen.

Dic hantering van 'n hiërargie of poel proficlvormnetwerke is wesenlik 'n databestuurskwessie. Die beoogde modelleringstelsel sal dié tegnologie moet insluit en die "intelligente" aspekte van ekspertstelsels moet benut as metodes om netwerke by situasies te pas. Dic uitvoerbaarheid van so 'n aanwending is deur Larsson en Persson ${ }^{35}$ gedemonstreer met hul rekenaargesteunde werk aan 'n "bevelspioen" om dic handelinge van 'n gebruiker dop te hou.

\section{Hoofparameters}

'n "Lêer" van hoofparameters word in baic gerekenarisecrde aanwendings gebruik. By gebouontwerp-evaluering kan dit gegewens soos die inllasickoers en dic sikliese beskikbaarheid van materiaal en arbeid insluit. Die algemene parameters-"leer" kan rec̈ls asook data insluit. Daar kan 'n fasilitcil vir "verspreide" reëls of 'n hiërargies geordende reëlbasis wees. Dit sal beteken dat dic inrocping van hoofparameters om dic impak van (sê) hecrsende ekonomiese toestande in te sluit, nic tot eenvoudige feitelike ol empiriese gegewens beperk sal word nie. Die "model" van hoofparameters sal self 'n ekspertstelsel met reëls en kennis wees.

Dic stelsel kan nou as 'n recks klein modelle, wat elk 'n segment van 'n ten volle geïntegreerde stelsel bydra, beskou word. Die stelsel sal vir die konsolidering van die tersaaklike stukke verantwoordelik wecs deur dic omstandighede te evalueer en die beste stel modules vir 'n spesifieke situasic te kies. Die konsep wat hicr geskets word, is reeds goed in rekenaarstelsels beproef. Dil word dikwels die "biblioteekstelsel" genoem en bied ' $n$ stel roctines of prosedures met algemene doelstellings vir gebruik in spesificke omstandighede. Die ekspertstelsel word so 'n biblioteck, met talle potensiële outeurs wat modules, gedeeltes, prosedures of stelle reëls bydra om verskillende toestande te dek. 'n Deskundige oor die beperking van energieverlies kan byvoorbeeld 'n stel reëls tot dic biblioteek bydra wat in dic algemene ontwerp van die verhittings- en verkoelingsubstelsels gebruik kan word. Dic ekspertstelsel behou steeds die taak om 'n situasic wat deur dic bourckenaar beskryf is, by 'n "soortgelyke" versameling reëls, gegewens en of netwerke wat binne die ekspertstelsel gestoor word, te pas.

Op grond van dić organisering van die "lêer" van hoofparameters word dit moontlik om dié "Iêcr" as 'n stel reëls tc beskou wat aan dic hand van dic konteks gekies moet word en in die algemene konstruksic van die volledige stelsel ingepas moet word.

\section{Geloruikers-koppelvlak}

Die gebruikers-koppelvlak word as 'n haic belangrike aspek van die stelsel beskou. Dit geld veral vir die alvoervertoning, aangesien dit grotendeels sal bepaal of die gebruiker die stelsel verstaan. Hoe meer eksplisiet die afvoer, hoe beter sal die gebruiker dic stelsel verstaan. Dic generering van groot hoeveelhede numeriese gegewens behoort opsioneel te wees, hoewel dit in sekere omstandighede onvermydelik is. Die klem is op doeltreflende alvoervertoning sonder dat die inligtingsbehoeftes van dic gebruiker afgeskeep word. Gebruikersbegrip kan bevorder word deur die gebruik van gralieke, kleur, driedimensionele stipwerk, histogramme en segmentkaarte.

In die lig van die noodsaak dat die modelleringsproses logies deurskynend en eksplisiet in sy veronderstellings moet wees, word die verduidelikingsfasiliteit as van besondere belang beskou. Dié fasiliteit moet met die vlak van sofistikasie van die gebruiker ooreenstem en terminologie gebruik waarmee dic gebruiker vertroud is.

Daar word voorgestel dat 'n evalueringstelsel wat van 'n docl terug kan beweeg, oorweeg moet word, dit wil sê doelwitbevrediging. Dić voorstel is gebaseer op dic beskrywing van "opinichersiening" aangebied deur Stefik el al. ${ }^{36}$ Die bourekenaar kan byvoorbecld in kennis gestel word dat die kliënt R15000 000,00 beskikbaar het vir dic bouprojek en graag wil weet wat vir dié bedrag verkry kan word. Die modelleringstelsel kan dan die volgende aksies oorweeg:

- Dic kliënt se doelwit is orn nie meer as R 15 miljoen te bestec nic.

- Uit dic databasis van projekte kan dic beskikbare geld by benadering onderverdecl word gebaseer op "soortgelyke" projekte waarvan die rekord in gemelde databasis gestoor word.

- Subdoel witte met betrekking tot gehaltespesifikasic, duur en/ of koste word vir elke bou-element gestel.

- 'n Poging word deur die stelsel aangewend om dié subdoclwitte op stelselmatige wyse te bevredig, en die bourckenaar word om ontbrekende of onvolledige gegewens gevra, na gelang hulle nodig word.

- Die bourckenaar kan dan dic argitek en kliênt meedecl wat hul opsies is binne die paramelers van die mate waarin gemelde subdoelwilte verwesenlik word.

- Ingeval die subdoclwitle nie bereikbaar is nic, kan die bourekenaar die rede vra en daardeur bewus'word van dic struikelblokke wat verhinder dat die ekspertstelsel goed werk.

- Moontlike remediërende aksie kan aanbeveel word, saam met die tersaaklike koste-/tydsgevolge.

Dić voorbecld van doclwitbevrediging is gebaseer op ' $n$ linansiële doelwit. Doelwitte kan in die praktyk egter ook in terme van gehaltespesifikasies of voltooiingstyd uitgedruk word.

Die kwessies belrokke in die validering van 'n ekspertstelsel word elders beskryf (byvoorbeeld Gaschnig et al. ${ }^{37}$ ). Vorige pogings om die geldigheid van ekspertstelsels in bouontwerpevaluering te valideer (byvoorbeeld Brandon et al..$^{5}$ het gekonsentreer op die raming van die mate van goedkeuring wat deskundiges verleen aan die oplossing wat deur die ekspertstelse voorgestel word. 'n Nuttige, bykomende benadering kan moontlik wees om dic ontwerplase van 'n reeds voltooide projek te herloop. Stelselafvocradvies kan dan met werklike resultate vergelyk word. Die basiese stappe in so 'n valideringsprosedure sal wees:

- die seleksic van 'n voltooide, goed gedokumenteerde projek;

- die invoer van die data op ontwerpsulak vir die voltooide projek in dic modelleringstelsel; en 
- die vergelyking van die advies oor koste, tyd en risikoontleding van die modelleringstelsel me dic gedokumentecrde resultate van die werklike projek.

Dić benadering tot validering wil verseker dat 'n stelsel wat in dic praktyk werk, ook in die teoric van tocpassing sal wees. Dié valideringstegnick sal ook moet evaluecr in welke mate dic a anvanklike sketsontwerp(c) en dic finale bouproduk ooreenstem.

\section{SLOTSOM}

Die motivering vir hierdic verhandeling behels en voorsien dic konscptucle raamwerk vir ' $n$ voorgestelde kostcmodelstelsel wat die docltreflende kommunikasic van bouprysboodskappe sal verhoog. Met inagneming van dic inherente afwesigheid van kousaliteit en logiese deursigtigheid van tradisionele prysmodelle, word daar voorgestel dat dic insluiting van kundigheid van dic bou-aannemer ten opsigte van bouplanmetodes in die prys-/kosteberaming die potensiaal het om dic intrapersoonlike kommunikasicproses wat daarmee gepaardgaan, te verhoog, en dus ook van bouprysboodskappe.

Daar word aangevoer dat ekspertstelseltcgnologic 'n gunstige klimaat skep om die geskikte gespesialiseerde kundigheid toeganklik te maak. Navorsing in verband met dic tocpassing van ekspertstelsels op boupryskostemodelle word hersien en krities geëvalueer. Die sintese van netwerkgebaseerde modelle en deskundige stelsels word voorgestel en 'n konseptucle raamwerk vir 'n netwerkgebascerde kostemodelstelsel word aanbeveel. Hierdie konseptuele raamwerk waarin gebruik gemaak word van teksgebasecrde kennisvoorstelling, word aangebied as ' $n$ voorgestelde rigting vir toekomstige navorsing.

Die voorgestelde modelleringstelsel word beskou as dinamics en betreklik buigbaar en die toepassing daarvan meer geskik vir proakticwe prysadvies as die tradisionele modelle. Met inagneming dat die stelsel verband sal hou mel die konstruksicbeplanningproses, die waarskynlikhcidskontekstuele afhanklikheidsdata benut, stogasties kwalifiserende produksie lewer en eksplisicte veronderstelling en logika genereer, word dic potensiaal daarvan as ' $n$ besluithulp en 'n vocrtuig vir dic beraming en kommunikasic van ontwerpkoste-implikasies voorgestaan. Daar word tot die gevolgtrekking gekom dat die belangrikste bydrac verbonde aan dic konseptucle model, dic waarnecmbare potensiaal is om die ineenlopende aard van die intrapersoonlike kommunikasieproses aan te help. Dic voorgestelde konseptuele raamwerk mak voorsicning vir dic proakticwe en sinvolle rol van die bourckenaar in die verskalfing van prysboodskappe.

\section{SumMary}

The pricing on construction projects necessitates the conversion of design decisions into construction resource implications. The conversion process is conducted through the medium of construction planning. Current construction planning practice relies heavily on the manual formulation of plans. The planning activity is usually performed in an intuitive and unstructured fashion, with considerable reliance being placed on judgement and experience not normally available during the pre-tender phase.

Developments in the field of artificial intelligence in general, and expert systems in particular, have made it possible for human expertise to be captured and structured to replicate the planning process, suggesting that the technology already exists for the task. Expert systems provide a means of externalising the thought processes of experts in such a manner that quantity surveyors can utilise the knowledge contained therein to supplement their own intrapersonal communication processes. Research in the development of automated plan generation systems suggests a means for accessing construction planning expertise during the pre-tender phase for the provision of Jesign10-cost advice.

A network-based approach to cost modelling, utilising an expert system environment and script-based knowledge representation, is perceived to constitute a suitable vehicle for the provision of design-to-cost advice and is suggested as a future research direction. Such a system, in contrast to the models traditionally utilised by quantity surveyors, would be capable of reflecting the manner in which construction costs are generated.

The proposed coneptual cost modelling system framework is considered to possess the potential to be an improvement on traditional price models in terms of its ability to enhance the intrapersonal communication process associated with provision of price messages. More specifically, the potential henefits to be derived from the proposed conceptual framework are that it would:

- Incorporate the construction planning process al a slage of design when such expertise is not normally available to the design team.

- Provide a direct link between design and construction by enabling the cost/time implications of a design solution on the construction process to be identilied and understood.

- Provide a vehicle for knowledge refinement and the attainment of greater understanding on the part of the quantity surveyor.

- Provide a means of accessing the thought processes of experts in such a manner that users could utilise that knowledge to supplement their own intrapersonal communication processes.

- Provide a relerence framework ("mind model") to be augmented by the expertise of individual practitioners.

Finally, the improvement in the quality of the intrapersonal communication process considered to result from the application of the conceptual framework should produce an improvement in the interpersonal process of communicating price messages. This, in turn, should facilitate the greater attainment of shared meaning and more elfective communication between the quantity surveyor and users of building price advice.

\section{IITERATUURVERWYSINGS}

1. Gray, C. (1986). "Intelligent" construction time and cost analysis, Construction Management and Economics, vol. 4. 135-150.

2. Cornick, T., Bowen, J. (1986). A knowledge-based "expert system" for brickwork cladding design and production. Proceedings of the C.J.B. IOth Triennial Congress Ad'ancing Building Technology, Washington, September, vol. 2, 659-666.

3. Vines, M., Walker, D.H.T. (1992). Developing a knowledge based expert system "CRABES" for brickwork fault diagnosis. Proceedings of the Second Annual Conference on Isspection. Appraisal, Repairs and Maintenance of Buildings and Stuctures, Jakarta, September.

4. Howes, R. (1992). "POEM" Project Management, Cost Control and Reporting System. User Manual (E.C. Harris, London).

5. Brandon, P.S., Basden, A., Hamilton, 1.W. en Stockley, J.E. (1988) Expert Systems: The Strategic Plaming of Construction Projects (Royal Institution of Chartered Surveyors, London).

6. Trimble, G., Bryman, A., Cullen, J. (1986). Knowledge acquisition for expert systems in construction. Proceedings of the C.I.B. 101 Triennial Congress Advancing Building Technology. Washington. 
September, vol. 2, 770-777

7. Kelly, J.R. (1987). Simulation models as generators of rules for expen systems. In Building Cost Modelling and Computers, P.S. Brandon ed. (E. \& F.N. Spon Lid., London) pp. 453-461.

8. Allwood, R.J., Stewart, D.J., Hinde, C., Negus, B. (1985). Evaluation of Expert System Shells for Construction Industry Applications. Report, Deparment of Civil Engineering, Loughborough University of Technology, Loughborough.

9. Bennett, J., Ormerod, R.N. (1984). Simulation applied to construction projects, Construction Management and Ecomomics, vol. 2, 225263.

10. Thompson, P.A., Willmer, G. (1985). "CASPAR" - A program for engineering project appraisal and management. Proceedings of the 2nd International Conference on Civil and Structural Engineering Computing, London, December, vol. 1, 75-81.

11. Bowen, P.A. (1993). A communication-based approach to price modelling and price forecasting in the design phase of the traditional building procurement process in South Africa. Unpublished Ph.D. Thesis, Department of Quantity Surveying, University of Port Elizabeth, Port Elizabeth.

12. Marston, V.K., Skitmore, R.M. (1990). Automatic resource based cost-time forecasts, Transactions, American Association of Cost Engineers, M.6. I-M.6.6.

13. Hendrickson, C., Zozaya-Gorostiza, C., Rehark, D., Baracco-Miller, E. (1987). Expert system for construction planning, Journal of $\mathrm{Com}$ puting in Civil Engineering, American Society of Civil Engineers, vol. I, no. 4, 253-269.

14. Newell, A., Simon, H. (1972). Human Problem Solving (Prentice Hall, New York).

15. Sacerdoti, E. (1975). A Structure for Plans and Behaviour, Techmical Report No. 109, SRI Institute.

16. Nillson. N.J. (1980). Principles of Arrificial Imelligence (Tioga Publishing Company, Palo Alto).

17. Formoso, C.T. (1991). A Knowledge Based Framework for Planning House Building Projects. Unpublished Ph.D. Tesis, Department of Surveying, University of Salford, Salford.

18. Levitt, R.E., Kunz, J.C. (1985). Using knowledge of construction and project management for automated schedule updating, Project Management, vol. 16, no. 5, 57-76.

19. Ibbs, C.W., De La Garza, J.M. (1988). Knowledge engineering for a construction scheduling analysis system. In Expert Systems in Comstruction and Structural Engineering. Adeli, H. ed. (Chapman and Hall, London) pp. 137-1.59.

20. Navinchandra, D., Sriram, D., Logeher, R.D. (1988). "GHOST": Project network generator, Journal of Computing in Civil Engineering, American Society of Civil Engineers, vol. 2, no. 3, 239-254.

21. Alshawi, M., Jaggar, D. (1989). An expert system to assist in the generation and scheduling of construction activities. Proceedings of the Al Civil-Comp., London, September.

22. Bowen, P.A., Erwin, G.J. (1989). Expert systems in building design evaluation, South African Journal of Science, vol. 85, no. 4,
251-257.

23. Silverman, B.G., Moustakis, V.S. (1987). Expert system issues in 'Innovator': representations and heuristics. In Expert Systems in Business, Silverman, B.G. ed. (Addison-Wesley, Reading, Massachuset(s) pp. 402-439.

24. Moselli, O., Nicholas, M.J. (1990). Hybrid expert system for construction planning and scheduling, Journal of Comstruction Engineering and Management, American Socicty of Civil Engineers, vol. 116, no. 2, 221-238

25. Boussabaine, A. (1991). An Exyert System Prototype for Construction Planning and Productivity' Analysis. Unpublished Ph.D. Thesis, Department of Building Engineering, University of Manchester Institute for Science and Technology, Manchester.

26. Allwood, R.J. (1986). Using expert system shells, Imernational Journal of Construction Management and Tec/mology, vol. 1, no. 3, 23-36

27. Allwood. R.J. (1989). Techniques and Application of Expert Systems in the Comstruction Industry (Ellis Horwood, Chichester).

28. Allwood, R.J. et al. (1987). Some experiences from evaluating expert system shell prograns and some potential applications. Proceedings of the International Conference Application of Artificial Intelligence Techmiques on Civil and Structural Engineering. London, 1-6.

29. Creative Logic Lid. (1989). Leomardo User Guide (Creative Logic Lid., Uxbridge).

30. Schank, R.C., Abelson, R.P. (1977). Scripts, Plans, Goals and Understanding: An Inquiry into Human Knowledge Structures (Lawrence Erlbaum Associates, Hillsdale, New Jersey).

31. Schank, R.C., Riesbeck, C.K. (eds.) (1981). Inside Computer Understanding: Five program.s plus minianures (Lawrence Erlbaum Associates, Hillsdale, New Jersey).

32. Waterman, D.A. (1986). A Guide o Expert Systems (AddisonWesley, Reading, Massachusetts).

33. Bowen, P.A., Erwin, G.J. (1994). Describing the building procurement process using script-based knowledge representation, Soull African Journal of Science, 90, 543-546.

34. Niwa, K. (1986). A knowledge-based human computer co-operative system for ilt-structured management domains, IEEE Transactions on Systems, Man and Cybernetics, SMC-16, no. 3, May/June. 33.5-342.

35. Larsson, J.E., Persson, P. (1986). Knowledge representation by scripts in an expert interface. Proceedings of the American Control Conference, 1159-1162.

36. Stefik, M., Aikins, J., Balzer, R., Benoit, J., Birnbaum, L., HayesRoth, F., Sacerdoti, E. (1983). Basic concepts for building expert systems. In Building Expert Systems, Hayes-Roth, F., Waterman, D.A. Lenat, D. eds. (Addison-Wesley, Reading, Massachusetts) pp. 59-86

37. Gaschnig, J., Klahr, P., Pople, H., Shortlille, E., Terry, A. (1983) Evaluation of expert systems: issues and case studies. In Building Expert Systems. Hayes-Roth, F., Waterman, D.A., Lenat, D. eds (Addison-Wesley, Reading, Massachusetts) pp. 241-280. 